\title{
Kraliçe Arı Fenomeni Bağlamında Özel Sektörde Çalışan Kadınlara Yönelik Nitel Bir Araştırma
}

\author{
A Qualitative Study of Women Working \\ in the Private Sector in the Context of the Queen \\ Bee Phenomenon
}

Hava Yaşbay Kobal*

\begin{abstract}
Öz
Çalışmada, Türkiye'de özel sektörde çalışan kadın yöneticilerin kraliçe arı davranışı gösterip göstermediği araştırılmaktadır. Araştırmada on sekiz kadın yönetici ve on beş kadın çalışanla yapılan görüşmelerden edinilen veriler NVivo 10 nitel veri analizi programında analiz edilmiştir. Sonuçlar, örneklemde yer alan kadın çalışanların olumlu özelliklerinin detaycılık, çok yönlülük ve empati kurabilme olduğunu göstermektedir. Olumsuz özellik ise duygusallıktır. Kadın çalışanların karşılaştığı zorluklar erkek egemen çalışma ortamları ve ailevi sorumluluklardır. Kadın yöneticilerin demokratik ya da durumsal yönetim tarzını benimsedikleri saptanmıştır. Kadın yöneticiler kadın çalışanlara kariyerlerinde yükselmeleri konusunda verdikleri desteği özellikle vurgulamışlardır. Kadın çalışanlar da kraliçe arı davranışıyla karşılaşmadıklarını aksine kadın yöneticilerin kendilerine karşı anlayış ve empatiyle yaklaştıklarını, kariyer gelişimleri konusunda desteklendiklerini ifade etmişlerdir. Bu nedenle örgütlerde kraliçe arı fenomenini ortadan kaldırmaktan ziyade cam tavan sendromunu ortadan kaldıracak stratejilerin hayata geçirilmesi önerilmektedir. Bu sayede kadınların başarılarına ve liyakatlerine bakılmaksızın yalnızca kadın oldukları için ilerlemelerinde karşılarına çıkan engelleri aşmak mümkün olacaktır.
\end{abstract}

* Dr. Öğr. Ü., Hakkari Üniversitesi, İktisadi ve İdari Bilimler Fakültesi, İşletme Bölümü, Yönetim ve Organizasyon Anabilim Dalı, havayasbay@ hakkari.edu.tr, 0000-0002-2589-785X

Başvuru: 20.04.2021

Kabul: 12.05. 2021

DOI: 10.21798/kadem.2021.51
This work is licensed under the Creative Commons Attribution 4.0 International License

Cite this article as: Kobal, H. Y. (2021). Kraliçe Arı Fenomeni Bağlamında Özel Sektörde Çalışan Kadınlara Yönelik Nitel Bir Araştırma, Kadem Kadın Araştırmaları Dergisi, Vol. 7, No. 1: 53-78. 


\begin{abstract}
This study examines whether women managers working in the private sector in Turkey show the queen bee behavior. The data obtained from interviews with 18 female managers and 15 female employees was analyzed in NVivo 10 qualitative data analysis programs. The results show that the positive characteristics of the female employees in the sample are elaboration, versatility, and empathy. The negative characteristic is emotionality. The difficulties faced by female employees are maledominated work environments and family responsibilities. It has been determined that female managers adopt a democratic or situational management style. Female managers especially emphasized their support for female employees to advance in their careers. Female employees also stated that they did not encounter queen bee behavior; on the contrary, female managers approached them with understanding and empathy and supported them in their career development. For this reason, it is recommended to implement strategies that will eliminate the glass ceiling syndrome rather than eliminate the queen bee phenomenon in organizations and companies. In this way, it will be possible to overcome the obstacles that women face in their advancement, regardless of their achievements and merits, simply because they are women.
\end{abstract}

\title{
Extended Abstract
}

The glass ceiling refers to the invisible but strong obstacles that prevent women and minority groups from advancing to senior management positions in organizations and reaching their full potential (Cannings, 1988; 87; Knutson ve Schmidgall, 1999:64; Jackson, 2001: 30; Lockwood, 2004:1; Hu ve Myeong-Su, 2008:1; Downes vd., 2014: 132; Lathabhavan, 2019:305). This is a barrier based on the fact that they are only women or a minority, not because they do not have job-related skills, education or experience as an accurate measure of performance (Cannings, 1988; 87; Stroh vd., 1996:102-103; Goodman vd., 2003: 475476). Although the benefits of gender diversity in organizational management have been clearly demonstrated, it is seen that women are not sufficiently represented in leadership positions. Women still face widespread gender stereotypes and gender discrimination as they try to climb the organizational ladder today. In organizations, it is assumed that such behaviors are mostly from men. However, it is suggested that women who are successful in male-dominated organizations may play a negative role in the advancement of their female subordinates. In a male-dominated society, the leader prototype is a masculine profile with masculine features, and women's sexual characteristics and roles do not exactly match this profile. This situation causes some female employees to develop a more supportive and tolerant style towards both 
genders, who go through similar processes. While some women executives move away from other women and fulfill their career goals, they also contribute to the gender stereotypes of their female subordinates and prevent their progress rather than encouraging it. This type of behavior is called queen bee syndrome. The aim of this study is to investigate whether women managers working in the private sector in Turkey demonstrate the queen bee behavior.

The positive characteristics of the female employees in the sample are their elaboration, versatility, and empathy. These results are consistent with Tekyazman's (2019) research results. The negative trait of female employees was determined to be emotionality. The difficulties faced by female employees are male domination in companies and family responsibilities they have. As long as there is prejudice against women in the organizational culture, putting women in management positions does not necessarily improve opportunities for other members of the same social group within the organization. Instead, the present results reveal the importance of reducing gender discrimination and prejudice as a feature of organizational culture and increasing the value placed on gender diversity. As another result of the research, it was determined that female managers adopt a democratic or situational management style.

Female employees stated that they did not encounter queen bee behavior from their female employers; on the contrary, female managers approach them with understanding and empathy, supporting their career development. These results contradict the results of the studies conducted by Ellemers et al. (2004), Derks vd. (2011a, 2011b, 2016), Faniko vd. (2016, 2020), Arvate vd. (2018), Permatasari ve Suharnomo (2019). On the other hand, the research results of Arvate et al. (2018) are in line with the results of the study.

One reason to improve gender diversity in organizations is to take advantage of the diversity of perspectives men and women bring into the organization. The queen bee phenomenon limits the ability of organizations to reap the benefits of gender diversity. When women feel that they have to adapt themselves to the male-dominated organizational culture in order to be accepted, they are unlikely to provide a different perspective. Thus, an appropriate solution to changing queen bee behavior and women's equality in organizations includes effectively reducing gender bias and taking steps to improve women's position. It is thought that queen bee behavior will disappear when women no longer see their gender as an obstacle in business life, or when they do not perceive queen bee behavior as a way to achieve success. For this reason, strategies that will eliminate the glass ceiling syndrome rather than eliminate the queen bee phenomenon should be implemented in 
organizations. In this way, it will be possible to overcome the obstacles that women face in their advancement solely because of their gender, regardless of their achievements and merits. In this sense, the most important measure that can be taken is to establish a fair organizational structure that will prevent gender inequality throughout the organization and to avoid suspicion in the minds of employees that they are subject to gender-based discrimination. Women managers who do not think that they face any gender-based discrimination will be fairer, more self-sacrificing, and more supportive in their attitudes towards their subordinates.

The results of the study are valuable in providing an alternative perspective to the popular notion that women in general tend to compete more than men and therefore are their worst enemies. However, the scope of the research is limited to female managers and female employees working in different fields in the private sector. In this sense, it is thought that it will be beneficial to repeat the study for women working in the public sector and to increase the number of studies on the queen bee phenomenon in future studies.

Anahtar Kelimeler: Cam tavan, cinsiyet ayrımcıllğı, kraliçe arı fenomeni, prenses arı etkisi, nitel analiz

Keywords: Glass ceiling, gender discrimination, queen bee phenomenon, queen bee effect, qualitative analysis

\section{Giriş}

Örgüt yönetiminde cinsiyet çeşitliliğinin faydaları açıkça ortaya konulmuş olsa da kadınların liderlik pozisyonlarında yeterince temsil edilmediği görülmektedir. Kadınlar bugün hâlâ örgüt merdivenlerini tırmanmaya çalışırken yaygın cinsiyet stereotipleri ve cinsiyet ayrımcılığıyla karşı karşıyadır. Araştırmacılar, kadınların iş yerinde yeteri kadar temsil edilmemesinin nedenlerini belirlemeye çalışmışlardır. İlk araştırmalar, özellikle erkekler arasında bariz olan cinsiyet ön yargısının rolünü ele almıştır. Erkek egemen örgütlerde başarılı olan kadınların, kadın astlarının ilerlemesinde olumsuz bir rol oynayabileceği öne sürülmektedir. Çünkü bu tür örgütlerde lider, erkeksi özellikler gösteren eril bir profildir ve kadının özellikleri bu profil ile tam olarak örtüşmemektedir. Yakın zamanlarda yapılan araştırmaların bazıları (Derks vd., 2011; Derks 
vd., 2016; Faniko vd., 2016), yüksek pozisyonlara ulaşan kadınların bazen diğer kadınların ilerlemesini desteklemediğini belgelemiştir. Diğer taraftan, İngiltere'nin ilk kadın başbakanı Margaret Thatcher (bkz. BBC News'in Reality Check ekibi, 2018; Moreton, 2015), kabinesindeki diğer kadınların kariyerlerini desteklemediği için dünya basınında "kraliçe arı" olarak adlandırılmıştır. Eski Dışişleri Bakanı Madeleine Albright'ın son ABD başkanlık seçimlerinde diğer kadınları Hillary'nin adaylığını desteklemeye çağırarak "Birbirine yardım etmeyen kadınlar için cehennemde özel bir yer var!" demiş, bu sözler dünya basınında büyük yankı uyandırmıştır (Arvate vd., 2018:533-535). Fakat bunlar genelleştirebilir örnekler değildir. Buradan hareketle bu çalışmanın amacı, Türkiye'de özel sektörde çalışan kadın yöneticilerin kraliçe arı davranışı gösterip göstermediğini araştırmaktır.

Araştırmanın amacı doğrultusunda, katılımcılarla yarı yapılandırılmış telefon görüşmeleri yapılmış ve elde edilen veriler Nvivo 10 nitel analiz programıla içerik analizine tâbi tutulmuştur. İçerik analizinde veriler kodlanmış ve kodlar arasındaki ilişkiler saptanarak tematik örüntüler ortaya çıkarılmıştır. Tematik örüntüler, temaların kendi içindeki ilişkisi ile görüşmelerden örnekler sunulmuş, ortaya konulan bulgular yorumlanarak birtakım sonuçlar elde edilmiştir.

\section{Cam Tavan ve Kraliçe Arı Fenomeni}

Cam tavan, kadınların ve azınlık grupların örgütlerde üst düzey yönetici pozisyonlarına ilerlemesini ve tam potansiyellerine ulaşmalarını engelleyen görünmez fakat güçlü engelleri ifade etmektedir (Cannings, 1988: 87; Knutson ve Schmidgall, 1999:64; Jackson, 2001: 30; Lockwood, 2004:1; Hu ve Myeong-Su, 2008:1; Downes vd., 2014: 132; Lathabhavan, 2019:305). Bu engel, performansın doğru bir ölçüsü olarak işle ilgili becerilere, eğitime veya deneyime sahip olmadıkları için değil, sadece kadın ya da azınlık oldukları gerçeğine dayanan bir engeldir (Cannings, 1988: 87; Stroh vd., 1996:102-103; Goodman vd., 2003: 475-476). 
Kadınlar bugün hâlâ örgüt merdivenlerini tırmanmaya çalışırken yaygın cinsiyet stereotipleri ve cinsiyet ayrımcılı̆̆ıyla karşı karşıyadır. Örgütlerde bu tür davranışların çoğunlukla erkeklerden geldiği varsayılmaktadır. Bununla birlikte, erkek egemen örgütlerde başarılı olan kadınların, kadın astlarının ilerlemesinde olumsuz bir rol oynayabileceği öne sürülmektedir. Yönetim kademelerine ulaşan kadınların diğer kadınların kariyer fırsatlarını iyileştirmek ve rol model olmak için motive oldukları görülse de bazı çalışmalarda (örneğin: Ellemers vd., 2004; Staines vd., 1974), kadın astların konumunu iyileştirme girişimlerini desteklemek yerine karşı çıktığı tespit edilmiştir. Bu kadın yöneticiler "Kraliçe Arılar" olarak tanımlanmıştır. Kraliçe arı ifadesi, ilk olarak Michigan Üniversitesi'nde araştırmacı olan Carol Tavris, Toby Epstein Jayaratne ve Graham Staines (1974) tarafından ortaya atılmıştır (Permatasari ve Suharnomo, 2019: 42).

Kraliçe arılar, liderlik pozisyonlarının çoğunun erkekler tarafından tutulduğu örgütlerde diğer kadınlardan uzaklaşarak kariyer hedeflerini yerine getirirken ayn zamanda kadın astların cinsiyet klişelerine katkıda bulunan, onların ilerlemesine yardımcı olmaktan çok onları engelleyen şekillerde davranan kadın yöneticilerdir (Arvate vd., 2018:534-535; Derks vd., 2011a: 519; Derks vd., 2011b: 1243; Derks vd., 2016:457; Faniko vd., 2016:903). Kraliçe arı davranışının, herhangi bir kadının özelliğinden çok kadınların erkek egemen örgütlerde karşılaştıkları cinsiyet ayrımcılığıyla ilgili olumsuz kariyer deneyimlerinin bir sonucu olduğu ifade edilmektedir (Arvate vd., 2018:535; Faniko vd., 2016:903-904; Salles ve Choo, 2020: 940). Kadınlar cinsiyetlerini bir sorumluluk olarak algıladıklarında, bu onları kraliçe arı davranışı yoluyla kariyerlerini ilerletmeye teşvik edebilir. Kraliçe arı bunu üç yolla yapmaktadır: (1) erkeksi özellikleri vurgulamak, (2) kendilerini diğer kadınlardan fiziksel ve psikolojik olarak uzaklaştırmak, (3) mevcut cinsiyet hiyerarşisini onaylamak ve meşrulaştırmak (Derks vd., 2011a: 520; Derks vd., 2011b:1244; Derks vd., 2016:456-457; Faniko vd., 2016:903). 


\subsection{Erkeksi Özellikleri Vurgulamak}

Örgütlerde üst yönetim kademelerine ulaşmak isteyen kadınların erkek egemen örgütlere uyum sağlamaya çalışmasının en bariz yolu, erkeksi özellikler ve liderlik tarzlarını vurgulamaktır. Başarılı liderlerin özellikleri ve kadınların cinsiyet rolleri hakkındaki ön yargılar uyumsuz olduğundan, kadınlar üst yönetim kademlerine ulaşma konusunda dezavantajlıdır. Bu nedenle, üst düzey yönetim kademelerine ulaşmak ve "örgütteki diğer kadınlardan farklı olduklarını kanıtlamak” (Arvate vd., 2018:535) için kadın yöneticiler kendilerini daha erkeksi, iddialı, hırslı, rekabetçi ve risk alan kişiler olarak tanımlayabilmektedir (Derks vd., 2016:457).

\subsection{Kendilerini Diğer Kadınlardan Fiziksel ve Psikolojik Olarak Uzaklaştırmak}

Kadın yöneticiler bazen diğer kadınların kariyerini iyileştirmeye çalışmak yerine, kendi kariyer firsatlarını geliştirmeye çalışılar. Bu tür bir davranış bireysel olarak fayda sağlasa da başarılı kadın yöneticilerin diğer kadınlardan uzaklaşmasına da yol açmaktadır (Derks vd., 2011b: 1244). Özellikle cinsiyet ön yargısının yüksek olduğu örgütlerde başarıya ulaşmış kadınlar daha erkeksi ve kariyerlerine daha bağlı olduklarını iddia ederek kendilerini diğer kadınlardan uzaklaştırabilmektedir (Derks vd., 2016:457). Ayrıca bu kadın yöneticiler genç kadınların yetkinliklerini ve hırslarını hafife alırlar, bu da onları genç kadınlara rehberlik ve kariyer fırsatları sunma konusunda isteksiz kılmaktadır (Permatasari ve Suharnomo, 2019: 43).

\subsection{Mevcut Cinsiyet Hiyerarşisini Onaylamak ve Meşrulaştırmak}

Bir örgütte başarılı olmuş kadın yöneticilerin, genellikle genç kadınlara ilham vermeleri ve onların liderlik pozisyonlarına gelmeleri için fırsatları arttırmaları beklenir. Fakat kraliçe arılar, cinsiyet hiyerarşisini çeşitli şekillerde meşrulaştırabilirler; örneğin, kra- 
liçe arılar, kadın astları çok eleştirerek ve onların erkek astlardan daha az hırslı ve kararlı oldukları ön yargısını onaylayarak, kadınları erkeklere kıyasla dezavantajlı konuma getiren önemli sonuçlarda mevcut cinsiyet farklılıklarını meşrulaştırmaktadır (Derks vd., 2016:457-458). Erkek egemen örgütlerde başarı elde eden kadınların, cinsiyet ön yargısına dair açık işaretler olsa bile seçim prosedürlerini meşru olarak algıladıklarını (Stroebe vd., 2009), cinsiyet ayrımcılığının örgütlerinde bir problem olduğunu inkâr ettiklerini gösteren (Derks vd., 2011) çalışmalar bulunmaktadır. Çünkü kraliçe arılar, mevcut konumlarını kendileri yaptıkları için başardıklarını bu yüzden diğer kadınların da tıpkı onun gibi yapabileceğini savunmaktadır. Dolayısıyla ayrımcılık nedeniyle kadınların kariyerlerinde ilerleyememe sebebini kabul etmezler (Permatasari ve Suharnomo, 2019: 43).

\section{Literatür İncelemesi}

Kraliçe arı fenomeni hakkında Ellemers vd. (2004) tarafindan yazılan makale dikkat çekicidir. Yazarlar, Hollanda ve İtalya'daki üniversitelerde; erkek ve kadın akademisyenlerin stereotip algilarının, kadınların akademide yetersiz temsil edilmesinin olası nedenlerini araştırmıştır. 1921 ve 1949 arasında doğan ve kendileri için istisnai olan bir dönemde akademik kariyere devam eden kadın öğretim üyelerinin, genç kadın akademisyenlerin kariyer hedeflerini küçümseme olasılıklarının erkek meslektaşlarından daha fazla olduğu sonucuna ulaşılmıştır. Dahası, kadın öğretim üyeleri kendilerini erkek meslektaşlarıyla eşit derecede erkeksi bir cinsiyet kimliğiyle tanımlamış, diğer kadınlardan farklı olduklarını vurgulamışlardır. Yazarlar bulguları dikkate alarak Staines vd. (1974) tarafından ortaya atılan kraliçe arı fenomenine atıfta bulunmuşlardır (Ellemers vd., 2004:332-333).

Derks vd. (2011a), kraliçe arı sendromunu besleyen örgütsel koşulları incelemişlerdir. Katılımcılar, Hollanda'da çeşitli şirketlerde üst düzey pozisyonlarda bulunan doksan dört kadından oluşmaktadır. Kraliçe arı sendromunun göstergeleri (artan cinsiyet ön 
yargısı, erkeksi öz tanımlamalar, diğer kadınlardan uzaklaşma) çoğunlukla kariyerine düşük cinsiyet kimliği ile başladığını belirten ve daha sonra yükselme yolunda yüksek derecede cinsiyet ayrımcılığı yaşayan kadınlarda bulunmuştur. Bu çalışmada, kraliçe arı olgusunun cinsiyet ayrımcılığının bir nedeni olmasının yanı sıra, örgütsel deneyimlerin önemli bir sonucu olduğunu, yani kadınların kariyerleri boyunca yaşadıkları cinsiyet ayrımcılığının önemli bir sonucu olduğunu göstermek için ilgili bir faktör olarak sosyal bağlama odaklanılmıştır. Kadınların yüksek derecede cinsiyet ön yargısına ve ayrımcılığa maruz kaldığı örgütlerin mevcut cinsiyet klişelerine uymaya sevk edebileceği (örneğin: "diğer kadınlar erkeklerden daha az kariyer odaklı") iddia edilmiştir. Bu tür bağlamlarda, kendini diğer kadınlardan ayırmak ("ben, istisna olarak, çok kariyer odaklıyım”), kadınların geliştirebilecekleri bir stratejidir. Ayrıca, tüm kadınların bu şekilde cinsiyet ayrımcılığından etkilenme ihtimalinin eşit olmadığı ancak özellikle örgütte kadın kimlikleriyle güçlü bir şekilde tanımlanmayan kadınların olumlu kariyer sonuçları için çabalarken kraliçe arı olma ihtimalinin yüksek olduğu belirtilmiştir (Derks vd., 2011a: 519-521).

Derks vd. (2011b), kıdemli polis kadın gruplarından kariyerleri sırasında cinsiyet ön yargısının varlığını veya yokluğunu hatırlamalarını istemişler ve kraliçe arı tepkilerini ölçmüşlerdir. Kraliçe arı fenomeninin çeşitli göstergelerini (artan cinsiyet ön yargısı, erkeksi öz tanımlamalar, diğer kadınlardan uzaklaşma) ve ayrıca kolektif eylem göstergelerini (kadınların sonuçlarını iyileştirmeyi amaçlayan programlara karşı olumlu tutumlar, kadın astların ilerlemesine yardımcı olma istekliliği) ölçmüşlerdir. Cinsiyet ön yargısına sahip ve düşük cinsiyet kimliği olan kadın polisler arasında kraliçe arı tepkilerinin fazla olduğu ancak cinsiyet kimliği yüksek olan kadın polislerin kraliçe arı tepkilerinin az olduğu sonucuna ulaşılmıştır. $\mathrm{Bu}$ sonuçlar, cinsiyete dayalı çalışma ortamlarının, düşük cinsiyet kimliğine sahip kadınları diğer kadınlardan uzaklaşmaya, cinsiyet ayrımcılığının yaygınlığını küçümsemeye ve kariyerde yükselmeyi sağlamanın bir yolu olarak kraliçe arı tepkilerini göstermeye teşvik ettiğini göstermektedir (Derks vd., 2011b: 1243-1244). 
Bickford (2011), başarılı kadınların büyük bir çoğunluğunun diğer kadın çalışanların kariyer gelişimlerini desteklediğini saptamıştır. Ayrıca bu kadın yöneticiler diğer kadınların başarılarını bir tehdit olarak algılamamakta ve bu başarılarla gurur duymaktadır. Bickford'a (2011) göre, 'kraliçe arı sendromu' bayatlamış cinsiyet ayrımcılığına dayalı bir ön yargıdan ibarettir.

Faniko vd. (2016), İsviçre'de yapılan bir çalışmayla 315 kadın işçi ile görüşerek kraliçe arı sendromunu araştırmışlardır. Araştırma sonuçlarına göre kadın yöneticiler kariyer deneyimi ve yaşam öncelikleri açısından kendileriyle benzer konumdaki kadınlarla özdeşleşmeye, onları desteklemeye oldukça istekli iken ailelerini ilk sıraya koyan kadın astları destekleme konusunda isteksizdiler (Faniko vd., 2016:903-904).

Derks vd. (2016), kraliçe arı tepkisinin kadınların kişiliklerinin veya diğer kadınlara karşı doğal rekabet gücünün tipik bir sonucu olmadığıını, kadınların değerinin düşürüldüğü ve olumsuz bir şekilde klişeleştirildiği erkek egemen çalışma ortamlarında tetiklendiğini bulgulamışlardır. Dezavantajlı grupların üyeleri bir azınlık konumunda olduklarında, muhtemelen gruplarının tipik özelliklerinin değer görmediğini veya önemli görülmediğini algılamaktadır. Dolayısıyla kraliçe arı olgusunun iş yerinde cinsiyet eşitsizliğinin ana nedeni olmaktan ziyade, bir sonucu olduğunu; özellikle kadınların cinsiyetlerini kariyer başarısı için bir yükümlülük olarak görmeye başladıkları bağlamlarda bulunduğunu, böylece kadınlardan uzaklaşmanın kişisel sonuçları iyileştirmenin bir yolu olduğunu iddia etmişlerdir. Kraliçe arılar işteki genç kadınlardan uzaklaşmış ve sadece benzer kariyer başarısı elde eden sınırlı kadın grubuyla özdeşleşmişlerdir (Derks vd., 2016:458-463).

Arvate vd. (2018), kadın liderliğinin kamu ve özel örgütlerde cinsiyet farklılıkları üzerindeki etkisini araştırmıştır. Sonuçlar, bir kadının yönetici olarak seçildiği örgütlerde üst ve orta kadın yönetici sayısında artış olduğunu göstermektedir. Fakat kraliçe arı fenomenin varlığına ilişkin kanıt bulunamamıştır. Bunun yerine, yönetimsel takdir yetkisine sahip kadın liderlerin, kadın astlarına 
karşı yardımsever bir şekilde davrandıkları saptanmıştır (Arvate vd., 2018:533,547).

Permatasari ve Suharnomo (2019), Endonezya'da bir şirkette çalışan kadınların kraliçe arı fenomeniyle ilgili deneyimlerini araştırmıştır. Sonuçlar, kraliçe arı özellikleri sergileyen yöneticinin korkutucu davrandığını ve çoğunlukla kadın astların kariyerini desteklemediğini göstermektedir. Ayrıca kraliçe arı sadece kadın astına değil, aynı zamanda iş yerindeki kadın meslektaşlarına da mesafe koymaktadır. Kraliçe arı olgusunun yarattığı olumsuz etkiler; astın strese girmesine neden olması, çalışma ortamının daha az elverişli, rahatsız edici hale gelmesi, örgütün faaliyetlerini aksatmasıdır (Permatasari ve Suharnomo, 2019: 41).

Kremer vd. (2019), kadın astların daha az destekleyici liderlerle karşı karşıya kaldıklarında, kraliçe arı davranışına iki şekilde cevap vererek kendilerini kadın liderlerinden uzaklaştıracağını iddia etmekte ve bu durumu prenses arı etkisi olarak adlandırmaktadır: 1) kendilerini kadın liderlerinden farklılaştırmak, 2) cinsiyet kimlikleriyle daha güçlü özdeşleşmek ve kendilerini daha kadınsı bir şekilde sunmak. İlk olarak, kadın astların kendilerini liderlerinden farklılaştırarak kraliçe arı davranışına tepki verecekleri tahmin edilmektedir. Çünkü daha erkeksi bir şekilde davranan kraliçe arılar karşısında kadın astlar onlarla ilişki kurmaktan kaçınabilirler. $\mathrm{Bu}$ durum kadın astlar için kendilerini aşağı çekenlerle ilişkilerini kesmeyi, kendi statülerini korumalarını ve bunun yerine destekleyici olanlarla daha fazla bağlantı kurmalarını teşvik edecektir. Kraliçe arılar, erkek egemen örgütlerde kariyer basamaklarını tırmanırken kendilerini daha erkeksi bir şekilde tanımlamaktadırlar. Kadın astların ise cinsiyetleriyle daha güçlü bir şekilde özdeşleşecekleri ve kendilerini kadınsı bir şekilde gösterecekleri iddia edilmektedir. $\mathrm{Bu}$ sayede, kadın astlar, kendilerini kraliçe arılardan daha uzak tutmanin ve cinsiyet stereotiplerine uygun hareket etmenin faydalarından yararlanabilmektedir. Diğer taraftan kadın astlar, kraliçe arılardan uzaklaşmanın ve cinsiyet stereotiplerine uygun hareket etmenin faydalarından yararlanmanın bir yolu olarak daha az yetkinlik yansitabilir (Kremer vd., 2019:3-4). 
Faniko vd. (2020), kraliçe arı fenomeninin akademisyenler arasında hâlâ bulunup bulunmadığını araştırmıştır. Bulgular, ilk olarak 2004 yılında Ellemers vd. tarafindan bulgulanan olgunun hâlâ var olduğunu göstermektedir. Buna göre, ileri yaşlardaki kadın akademisyenlerin, akademik kariyerlerinin başında bulunan kadınların kariyer bağlılıklarını küçümseme olasılıkları erkek meslektaşlarından daha fazladır. Aynı zamanda, ileri kariyer aşamalarındaki kadın akademisyenler, kendilerini erken kariyer aşamalarındakilere göre daha erkeksi terimlerle tanımlamaktadır. Bunun, başarılı kadınların erkeksi çalışma ortamını taklit ettikleri bir tepki modeli olduğu ifade edilmektedir (Faniko vd., 2020: 1).

Tolay (2020), farklı sektörlerden 40 kadın çalışanla görüşmeler yaparak; kadın çalışanların kadın yöneticileri hakkındaki algılarını ve iş yaşamında kadınlar arasındaki hiyerarşik ilişkilerini araştırmıştır. Araştırma sonucunda katılımcıların yarısı kadın yönetici ile çalışmanın "güzel, rahatlatıcı ve güven verici bir duygu" olduğunu belirtirken diğger yarısı "kötü, rahatsız ve tedirgin edici bir duygu" olduğunu ifade etmiştir. Kadın çalışanlar, kadın yöneticiler tarafından daha iyi anlaşıldıklarını dile getirmişlerdir. Ayrıca, iş ilişkisinde olması gereken resmiyetin, kadın ast ve üstler arasında korunamaması bazen sınırların aşılmasından duyulan rahatsızlık dile getirilmiştir.

Bu çalışmalar, kraliçe arı davranışının bazı kadınların davranış şekline veya örgütte birbirleriyle nasıl etkileşime girdiklerine indirgenemeyeceğini göstermektedir. Bunun yerine örgütsel bağlamdaki faktörlerin, cinsiyet eşitsizliğine maruz kalmanın, olumsuz kariyer deneyimlerinin ve örgütsel destek eksikliğinin kraliçe arı davranışının açıklanmasına katkıda bulunduğu ifade edilebilir.

\section{Yöntem}

Çalışmanın amacı, Türkiye'de özel sektörde çalışan kadın yöneticilerin kraliçe arı davranışı gösterip göstermediğini araştırmaktır. Araştırmanın sorusu; Türkiye'de özel sektörde çalışan kadın yöneticiler kraliçe arı davranışı sergilemekte midir? şeklindedir. 
Çalışmada amaçlı örnekleme yöntemlerinden maksimum çeşitlilik örneklemesi yöntemi kullanılmıştır. Bu bağlamda, finans, ilaç, elektronik, iletişim, otomotiv, eğitim gibi farklı sektörlerden otuz üç kadınla telefon görüşmeleri yapılmıştır. Maksimum çeşitlilik örneklemesinde örneklem, problemle ilgili olan ve kendi içinde benzeşik, değişken ve farklı durumlardan oluşacak şekilde belirlenmektedir (Grix, 2001). Bu doğrultuda genelleme yapmak için bu çeşitliliği sağlamak değil, çeşitlilik gösteren durumlar arasında herhangi ortak olguların olup olmadığını bulmaya çalışmak ve bu çeşitliliğe göre problemin farklı boyutlarını incelemek hedeflenmektedir (Baltac1, 2018:249).

Çalışmada nitel araştırma yöntemi kullanılmıştır. Türkiye'de çeşitli sektörlerde çalışan kadın yöneticiler ve kadın astlarla telefon görüşmeleri yapılmıştır. Veri toplama süreci Şubat 2021'de başlamış, Nisan 2021'de sona ermiştir. Elde edilen veriler hiçbir değişiklik yapılmadan deşifre edilerek Nvivo 10 nitel veri analizi programına kaydedilmiş ve içerik analizi yapılmıştır. İçerik analizinde veriler kodlanmış ve kodlar arasındaki ilişkiler saptanarak temalar ortaya çıkarılmıştır. Son olarak ortaya konulan bulgular yorumlanarak birtakım sonuçlar elde edilmiştir.

\section{Bulgular}

Araştırma kapsamında görüşme talebine yanıt veren otuz üç kadın örneklemi oluşturmuştur. On sekiz kadın yönetici ve on beş kadın çalışanla yarı yapılandırılmış telefon görüşmeleri yapılmıştır.

\subsection{Demografik Özellikler}

Katılımcılara ait demografik özelliklere Tablo 1'de yer verilmiştir. 
Tablo 1: Katılımcılara Ait Demografik Özellikler

\begin{tabular}{|c|c|c|c|}
\hline & & Kadın Yönetici & Kadın Ast \\
\hline & & $\mathbf{n}$ & $\mathbf{n}$ \\
\hline \multirow[t]{4}{*}{ Sektör } & Finans & 2 & 4 \\
\hline & İlaç & 4 & 5 \\
\hline & Elektronik & 6 & 1 \\
\hline & İletişim & 1 & 4 \\
\hline \multirow[t]{4}{*}{ Yaş } & $25-34$ & 1 & 8 \\
\hline & $35-44$ & 11 & 7 \\
\hline & $45-54$ & 4 & - \\
\hline & 55 ve üzeri & 2 & - \\
\hline \multirow[t]{4}{*}{ Çalışma Süresi } & 2 yılın altında & - & 1 \\
\hline & 3-5 y1l & - & 10 \\
\hline & 6-9 yil & 1 & 2 \\
\hline & 10 yıl ve üzeri & 17 & 2 \\
\hline \multirow[t]{2}{*}{ Medeni Durum } & Evli & 12 & 10 \\
\hline & Bekar & 6 & 5 \\
\hline \multirow{2}{*}{$\begin{array}{l}\text { Çocuk Sahibi } \\
\text { Olma }\end{array}$} & Evet & 15 & 11 \\
\hline & Hayır & 3 & 4 \\
\hline
\end{tabular}

Tablo 1 incelendiğinde kadın çalışanların altı tanesinin finans; dokuz tanesinin ilaç; yedi tanesinin elektronik ve beş tanesinin iletişim sektöründe çalıştığı görülmektedir. Görüşmeye katılan kadın yöneticilerin yarısından fazlası 35-44 yaş aralığındadır ve yaş ortalaması 43,5’tir. Kadın astların yarısı 25-34 yaş aralığında iken, diğer yarısı 35-44 yaş aralığındadır ve yaş ortalaması 33,7'dir. Kadın yöneticilerin ortalama çalışma süresi on iki yıl iken; kadın astların çalışma süresi ortalama beş yıldır. Bu durum, kadın yöneticilerin yaş aralığının kadın astlara göre daha yüksek olmasıyla açıklanabilir. Kadın yöneticilerin ve kadın astların çoğunluğunun evli ve çocuk sahibi olduğu saptanmıştır. 


\section{2. İş Hayatında Kadın (AT1)}

"İş Hayatında Kadın" ana teması "Kadınların Artı Yönleri" (T1), "Kadınların Eksi Yönleri” (T2) ve "Kadınların Karşılaştığı Zorluklar" (T3) olarak üç tema altında toplanmıştır.

Tablo 2: İş Hayatında Kadına İlişkin Temalar, Kodlar ve Frekanslar

\begin{tabular}{|l|l|l|l|}
\hline Ana Tema & Temalar & Kodlar & Referans \\
\hline \multirow{2}{*}{$\begin{array}{l}\text { İş } \\
\text { Hayatında } \\
\text { Kadın }\end{array}$} & $\begin{array}{l}\text { Kadının Olumlu } \\
\text { Özellikleri (T1) }\end{array}$ & Detaycılık (k1) & 11 \\
\cline { 3 - 4 } & Çok Yönlülük (k2) & 9 \\
\cline { 3 - 4 } & $\begin{array}{l}\text { Empati Kurabilme } \\
(\mathrm{k} 3)\end{array}$ & 9 \\
\cline { 2 - 4 } & $\begin{array}{l}\text { Kadının Olumsuz } \\
\text { Özellikleri (T2) }\end{array}$ & Duygusallık (k4) & 13 \\
\cline { 2 - 4 } & $\begin{array}{l}\text { Kadının Karşılaştı̆̆ı } \\
\text { Zorluklar (T3) }\end{array}$ & Ailevi Zorluklar (k5) & 7 \\
\cline { 3 - 4 } & $\begin{array}{l}\text { Erkek Egemenliği } \\
(\mathrm{k} 6)\end{array}$ & 13 \\
\hline
\end{tabular}

\subsubsection{Kadınların Olumlu Özellikleri (T1)}

"Kadınların Olumlu Özellikleri" teması, "Detaycılık" (k1), "Çok Yönlülük" (k2) ve "Empati Kurabilme" (k3) olarak üç adet kod içermektedir. Katılımcıların ifadelerinden alıntılara aşağıda yer verilmiştir:

k1- (...) Kadınlar daha detaya giriyor. Daha çok hassas bilgi istiyor. Bir rapor hem şık hem pratik olsun istiyor (6. yönetici)

k2- (...) Kadınlar bir kere çok yönlü çalı̧̧abilen insanlardır. Erkekler tek konuya uyum sağlayabilirken kadınlar ev işi, çocuk vs. aynı anda yapabilir (6. kadın ast)

k3- (...) Empati daha fazla olabiliyor tabi. Karşı tarafı daha iyi anlayabiliyor (10. yönetici) 


\subsubsection{Kadınların Olumsuz Özellikleri (T2)}

"Kadınların Olumsuz Özellikleri" teması, "Duygusallık" (k4) olarak bir adet kod içermektedir. Katılımcıların ifadelerinden alıntılara aşağıda yer verilmiştir:

k4- (...) Ama tabi işin çok duygusallaştırma boyutu var kadınlar tarafında. Kişisel algılamak, konuları. Altında başka şeyler aramak (16. yönetici)

\subsubsection{Kadınların Karşılaştığı Zorluklar (T3)}

"Kadınların Karşılaştığı Zorluklar" teması, "Ailevi Zorluklar" (k5) ve "Erkek Egemenliğii" (k6) olarak iki adet kod içermektedir. Katılımcıların ifadelerinden alıntılara aşağıda yer verilmiştir:

k5- (...) Her şeyden önce kadın yöneticinin her şeye yetişme çabası. Evdeki ailesi ve çocuğu olan kadın yönetici için özellikle kendi içinde yaşadiğı zorluk hem ev tarafındaki işleri hem de iş yerindeki işleri yüklenmek (1. yönetici)

k6- (...) Aslında doğalarından gelen özellikleri bakımından erkeklerin baskın olduğu, daha dominant, daha sertliğin hâkim olduğu ona ihtiyaç duyulan bir profil gibi algılanıyor yöneticilik. Kadınların aslında o noktada kendilerini buna uydurma çabasinda olduğunu görüyorum. Çok fazla doğuştan gelen özelliklerini, yetkinliklerini ve yatkınlıklarını çok fazla ön plana getirmek istemediklerini görüyorum kadınların yöneticiliklerinde. O kalipların içinde kalıp daha sert, daha erkeksi, daha bazi hassasiyetlerini saklamak isteyen profiller var. Bu beklentiye uyanlar o noktaya geliyor olabilir. Uyamayanlar gelemiyor olabilir (12. yönetici) 


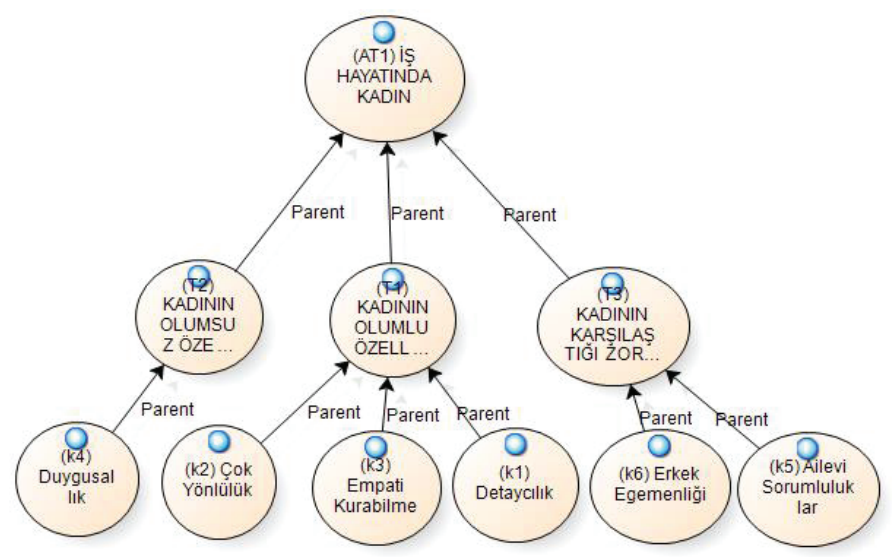

Şekil 1: İş Hayatında Kadına İlişkin Tema ve Kodlar Nvivo Modeli-1

\subsection{Kadın Yönetici (AT2)}

"Kadın Yönetici" ana teması "Yönetim Tarzı" (T4) ve "Kadın Astlara Destek" (T5) olarak üç tema altında toplanmıştır.

Tablo 3: Kadın Yöneticiye İlişskin Temalar,

Kodlar ve Frekanslar

\begin{tabular}{|l|l|l|c|}
\hline $\begin{array}{l}\text { Ana } \\
\text { Tema }\end{array}$ & Temalar & Kodlar & Referans \\
\hline $\begin{array}{l}\text { Kadın } \\
\text { Yönetici }\end{array}$ & Yönetim Tarzı (T4) & Demokratik (k7) & 11 \\
\cline { 2 - 4 } & $\begin{array}{l}\text { Durumsal (k8) } \\
\text { Kestek (T5) }\end{array}$ & $\begin{array}{l}\text { Kariyerde Yükseltme } \\
(\mathrm{k} 9)\end{array}$ & 18 \\
\cline { 2 - 4 } & Anlayış, Empati (k10) & 4 \\
\hline
\end{tabular}

\subsubsection{Yönetim Tarzı (T4)}

"Yönetim Tarzı" teması, "Demokratik" (k7) ve "Durumsal" (k8) olarak iki adet kod içermektedir. Katılımcıların ifadelerinden alıntılara aşağıda yer verilmiştir: 
k7- (...) Herkese eşit uzaklıkta, yönlendirici ama zorlayıcı değil. Demokratik aslinda (2. yönetici)

k8- (...) Yüzde yüz demokratik yaklaşım belki başka ülkelerde çalışıyordur ama Türkiye'de çok çalışmadı̆̆ını gördüm. Çok fazla demokrasi bir yerden sonra iyiyle kötüyü ayırmada zorluk oluyor. Herkese eşit davranırsan canını dişine takmış bir insanın bir farkını yaratmazsan o çok çalışan insanı da kaybedersin. O yüzden bir noktada bunun harmanı diyebiliriz. Otokratik zaten uluslararası hiçbir firmada istesen de yapamazsin. Bir yerden sonra seni zaten kurumsal iş yapma şekilleri engeller. Patron şirketi statüsünde olmadığı sürece o tarz bir yönetim şekli mümkün değil. Fabrika yönetiyorsun 128 kişi. Orada demokrasi çalışmaz ama Ar-ge grubu yönettim. Yazllımcllar. Orada \%100 demokrasi yapabilirsin. Biri diyor ki ben Siemens'te kalayım. Burada kariyer yapayım. Hatta mümkünse Siemens'te uluslararası diğer ülkelerdeki pozisyonlara geçeyim. Mavi yakanın ise ama saatimi doldurayım gideyim. Çok farklı (8. yönetici)

\subsubsection{Kadın Astlara Destek (T5)}

"Kadın Astlara Destek" teması, "Kariyerde Yükseltme" (k9) ve "Özel Hayata Destek" (k10) olarak iki adet kod içermektedir. Katılımcıların ifadelerinden alıntılara aşağıda yer verilmiştir:

k9- (...) Grup yöneticilerinin ve insan kaynaklarının işe alım sürecinde farkındalıklarının artması. Burada da mülakatlarda son ikiye mutlaka bir kadın ve bir erkeğin kalmasını sağlıyoruz. Kadın sayısını bu şekilde arttırdık. Bizim amacımız kötü bir kadını almak değil en iyi kadını almak. Burada da bugüne kadar pozitif ayrımcilı yapıyorduk ama bundan sonra onu yapmayacă̆ız. Diyoruz ki kadınlar da erkeklerle aynı seviyededir. Aynı zamanda cinsiyetsiz sözcükler çalışmasını yapıyoruz. Mesela şirkette "adam saat” demiyoruz, "çalışan saat" diyoruz. Işini “adam gibi yap” demiyoruz "insan gibi yap” diyoruz. Bütün iş süreçlerimizde erkek odaklı terim varsa bunların karşılığında yeni kelimeler kullanmayı teşvik ediyoruz. Son aşamada da 
şirkette halihazırda çalışan kadın mühendislerin teknik seviyelerini arttırmak için teknik geziler düzenliyoruz. Ya da eğitimler düzenliyoruz. Onları önceliklendiriyoruz. Çünkü şikayetler hep mesela bir yurt dışı eğitimi olursa yöneticim erkeği gönderiyor beni göndermiyor şeklinde oluyor. Bunu ortadan kaldırmak için öncelikli olarak kadınlara eğitim verdirmeye, onların görünür olmasını teşvik etmeye çalışıyoruz. 2014'ten beri yürüttüğümüz bu çalışmalar neticesinde özellikle bu sene çok olumlu geri dönüşler aldık. Farkındalık çok arttı. Kimse yadırgamıyor. Bir kadın olduğu için yöneticilik pozisyonu aldı̆̆ında kadın olmasına ră̆men başardı algısını yıkıyoruz (15. yönetici)

k10- (...) Biz kurumsal şirkette olduğumuz için, diğer yandan da kadınlarla ilgili çalışmaların olmasının da bir etkisi var diye düşünüyorum. Bugün mesela dikkatimi çeken bana bă̆lı değil ama bir arkadaşımız var doğum izninde olan. Benim onay vermem gereken bir şeyde fark ediyorum ki bir adımda da o arkadaşımız onay vermiş. Yöneticisine yardım. "Doğum izninde çalıştırmıyoruz değil mi?” diye. Erkekler bu hassasiyetle yaklaşamayabiliyor. Benim de başımdan geçtiği için bu hassasiyetle yaklaşıyorum. Ben bunu pozitif ayrımcılık olarak görmüyorum. Hakkı olanı vermek (13. yönetici)

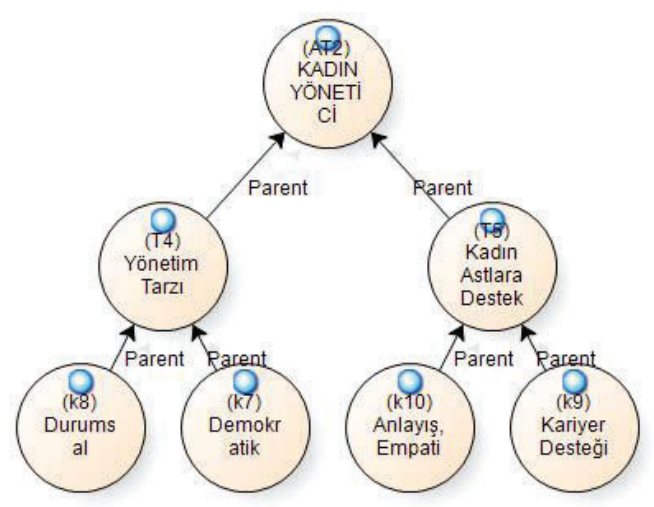

Şekil 2: Kadın Yöneticiye İlişkin Tema ve

Kodlar Nvivo Modeli-2 


\subsection{Kadın Çalışan (AT3)}

"Kadın Çalışan" ana teması "Kadın Yöneticiden Destek" (T6) teması altında toplanmıştır.

Tablo 4: Kadın Yöneticiye İlişkin Temalar, Kodlar ve Frekanslar

\begin{tabular}{|c|c|c|c|}
\hline Ana Tema & Tema & Kodlar & Referans \\
\hline \multirow{2}{*}{$\begin{array}{l}\text { Kadın } \\
\text { Çalışan }\end{array}$} & \multirow{2}{*}{$\begin{array}{l}\text { Kadın Yöneticiden } \\
\text { Destek (T6) }\end{array}$} & $\begin{array}{l}\text { Anlayış, Empati } \\
(\mathrm{k} 11)\end{array}$ & 14 \\
\hline & & $\begin{array}{l}\text { Kariyer Desteği } \\
(\mathrm{k} 12)\end{array}$ & 12 \\
\hline
\end{tabular}

\subsubsection{Kadın Yöneticiden Destek (T6)}

"Kadın Yöneticiden Destek" teması, "Anlayış, Empati” (k11) ve "Kariyer Desteği”" (k12) olarak iki adet kod içermektedir. Katılımcıların ifadelerinden alıntılara aşağıda yer verilmiştir:

k11- (...) Kadın yöneticiyle çalışmak çok daha faydalı diye düşünüyorum. Çünkü neden? Bir belki anne, belki teyze, belki hala olabiliyor. Mesela benim bir personelimin çocuğu okula gidecekti mesela benden ciddi anlamda bilgi alıp o okula gönderdi. Erkek yöneticiyle bu kadar detaylı konuşamayabilirsin. Bu kadar detay bilmeyebilir erkek yönetici (13. kadın ast)

k12- (...) Ben birebir desteklendim. İki tane kadın yöneticiye bağllydım bir dönem. Onlar performansımı görüp birebir taa üst yönetime çıkıp hiçbir bilgim olmadan iki kere bana ekstra zam yaptırdılar. Kariyer planımı çizmek için insan kaynaklarıyla masaya oturttular. Bana yön verdiler açık açık. İlerlemek için bunu yapman lazım. Gel seninle şuna gidelim. İşinle ilgili şu sunumu yapalım (9. kadın ast) 


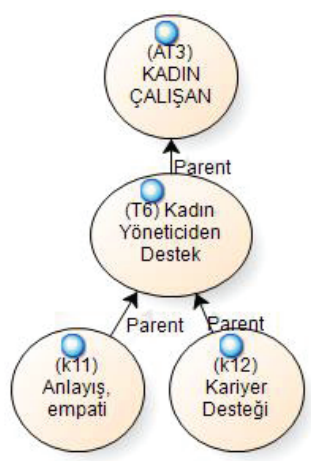

Şekil 3: Kadın Çalışana İlişkin Tema ve Kodlar Nvivo Modeli-3

\section{Tartışma ve Sonuç}

Çalışmada, Türkiye'de özel sektörde çalışan kadın yöneticilerin kraliçe arı davranışı gösterip göstermediği araştırılmaktadır.

Araştırma kapsamında görüşme talebine yanıt veren otuz üç kadın örneklemi oluşturmuştur. On sekiz kadın yönetici ve on beş kadın çalışanla yarı yapılandırılmış telefon görüşmeleri yapılmıştır. Kadın çalışanların altı tanesi finans; dokuz tanesi ilaç; yedi tanesi elektronik ve beş tanesi iletişim sektöründe çalışmaktadır. Görüşmeye katılan kadın yöneticilerin yarısından fazlası 35-44 yaş aralığındadır ve yaş ortalaması 43,5’tir. Kadın astların yarısı 25-34 yaş aralığında iken, diğer yarısı 35-44 yaş aralığındadır ve yaş ortalaması 33,7'dir. Kadın yöneticilerin ortalama çalışma süresi on iki yıl iken; kadın astların çalışma süresi ortalama beş yıldır. Bu durum, kadın yöneticilerin yaş aralığının kadın astlara göre daha yüksek olmasıyla açıklanabilir. Kadın yöneticilerin ve kadın astların çoğunluğunun evli ve çocuk sahibi olduğu saptanmıştır. Evli olmak ve özellikle çocuk sahibi olmak; aile ve iş sorumluluklarını aynı anda yüklenmek anlamına gelmekte; bu durum hem kadın yöneticiler hem de kadın astlar için kariyer hayatında yükselme açısından bir zorluk olarak değerlendirilmektedir. 
Örneklemde yer alan kadın çalışanların olumlu özellikleri detaycı olmaları, çok yönlülük ve empati kurabilmedir. Bu sonuçlar Tekyazman'ın (2019) araştırmasının sonuçlarıyla tutarlıdır. Kadın çalışanların olumsuz özelliği, duygusallık olarak saptanmıştır. Kadın çalışanların karşılaştığı zorluklar ise örgütlerdeki erkek egemenliği ve sahip oldukları ailevi sorumluluklardır. Örgütsel kültür ön yargılı kaldığı sürece, kadınları yönetim pozisyonlarına getirmenin, örgütteki aynı sosyal grubun diğer üyeleri için fırsatları mutlaka iyileştirmez (Derks vd., 2011a: 532). Bunun yerine, mevcut sonuçlar, örgüt kültürünün bir özelliği olarak cinsiyet ayrımcılığını ve ön yargıyı azaltmanın ve cinsiyet çeşitliliğine verilen değeri arttırmanın önemini ortaya koymaktadır. Diğer taraftan, kadın yöneticilerin demokratik ya da durumsal yönetim tarzını benimsedikleri görülmüştür. Kadın yöneticiler kendileriyle birlikte çalışan kadınlara kariyerlerinde yükselmeleri konusunu verdikleri desteği özellikle vurgulamışlar; bunun yanı sıra özel hayatlarında destek verdiklerini de belirtmişlerdir.

Kadın çalışanlar da kraliçe arı davranışıyla karşılaşmadıklarını aksine kadın yöneticilerin kendilerine karşı anlayışlı ve empatiyle yaklaştıklarını ve kariyer gelişimleri için desteklediklerini ifade etmişlerdir. Bu sonuçlar, Ellemers vd. (2004), Derks vd. (2011a, 2011b, 2016), Faniko vd. (2016, 2020), Arvate vd. (2018), Permatasari ve Suharnomo (2019) ve Tolay (2020) tarafindan yapılan araştırmaların sonuçlarıyla çelişirken; Bickford (2011), Er ve Adıgüzel (2015) ve de Arvate vd. (2018) tarafından yapılan çalışmanın sonuçlariyla paralellik göstermektedir.

Örgütlerde cinsiyet çeşitliliğini iyileştirmenin bir nedeni, kadın ve erkeklerin örgüte getirdiği bakış açısı çeşitliliğinden yararlanmaktır. Kraliçe arı fenomeni, örgütlerde cinsiyet çeşitliliğinin faydalarını elde etme yeteneğini kısıtlamaktadır. Çünkü kadınlar kabul edilmek için kendilerini erkek egemen örgüt kültürüne uydurmaları gerektiğini hissettiklerinde, farklı bir bakış açısı sağlama ihtimalleri düşüktür. Dolayısıyla, örgütlerde kraliçe arı davranışlarını ve kadınların eşitliğini değiştirmeye yönelik uygun bir 
çözüm, cinsiyet ön yargısı deneyimlerini etkin bir şekilde azaltmayı ve kadınların konumunu iyileştirmek için adımlar atmayı kapsamaktadır. Kadınlar artık iş yaşamında cinsiyetlerini bir yükümlülük olarak görmediklerinde veya kraliçe arı davranışını başarıya ulaşmanın bir yolu olarak algılamadıklarında kraliçe arı davranışlarının ortadan kalkacağı düşünülmektedir. Araştırmanın sonuçları, genel olarak kadınların erkeklerden daha fazla rekabet etmeye meyilli ve bu nedenle kadınların kendilerinin en kötü düşmanları olduğu şeklindeki popüler fikre alternatif bir bakış açısı sunması açısından değerlidir. Araştırmanın kapsamı özel sektörde farklı alanlarda çalışan kadın yöneticiler ve kadın çalışanlarla sınırlıdır. $\mathrm{Bu}$ anlamda, gelecek araştırmalarda, çalışmanın kamu sektöründe çalışan kadınlar açısından tekrarlanmasının ve kraliçe arı fenomenine ilişkin çalışmaların sayısının arttırılmasının yararlı olacağı düşünülmektedir.

\section{Kaynakça}

Arvate, P.R., Galilea, G.W. ve Todescat, I. (2018). The queen bee: A myth? The effect of top-level female leadership on subordinate females. The Leadership Quarterly, 29, 533-548.

Baltacı, A. (2018). Nitel araştırmalarda örnekleme yöntemleri ve örnek hacmi sorunsalı üzerine kavramsal bir inceleme. Bitlis Eren Üniversitesi Sosyal Bilimler Enstitüsü Dergisi, 7(1), 231-274.

Bickford, N. (11 Ekim 2011). 'Queen bees - an evolving species or an office myth?'. https://www.ft.com/content/9bc76152-f3f9-11e0-b22100144feab49a.

Cannings, K. (1988). Managerial promotion: The effects of socialization. Specialization, and Gender, ILR Review, 42(1), 77-88.

Derks, B., Laar, C. V. ve B., Ellemers (2016). The queen bee phenomenon: Why women leaders distance themselves from junior women. The Leadership Quarterly, 27, 456-469.

Derks, B., Ellemers, N., Laar, C. V. ve Groot, D.K. (2011a). Do sexist organizational cultures create the Queen Bee?. British Journal of Social Psychology, 50, 519-535. 
Derks, B., Laar, C. V., Ellemers, N. ve Groot, D.K. (2011a). Gender-Bias primes elicit queen-bee responses among senior policewomen. Psychological Science, 22(10), 1243-1249.

Downes, M., Hemmasi, M. ve Eshghi, G. (2014). When a perceived glass ceiling impacts organizational commitment and turnover intent: The mediating role of distributive justice. Journal of Diversity Management, 9(2), 131-146.

Ellemers, N., van den Heuvel, H., de Gilder, D., Maass, A. ve Bonvini, A. (2004). The underrepresentation of women in science: Differential commitment or the queen bee syndrome?. British Journal of Social Psychology, 43, 1-24.

Er, O. ve Adıgüzel, O. (2015). Cam tavan gölgesindeki kraliçe arılar: Kadınların kariyer ilerlemelerinde karşılaştıkları engeller ve etkili liderlik. Recep Tayyip Erdoğan Üniversitesi Sosyal Bilimler Dergisi, 2, 163-175.

Faniko, K., Ellemers, N. ve Derks, B. (2020). The queen bee phenomenon in Academia 15 years after: Does it still exist, and if so, why?. British Journal of Social Psychology, July, 1-17.

Faniko, K., Ellemers, N. ve Derks, B. (2016). Queen bees and alpha males: Are successful women more competitive than successful men?. European Journal of Social Psychology, 46, 903-913.

Grix, J. (2001). Demystifying postgraduate research from MA to PHD. London: The University of Birmingham.

Hu, T. ve Myeong-Su, Y. (2008). Is the glass ceiling cracking? A simple test, IZA Discussion Papers 3518, Institute of Labor Economics (IZA).

Jackson, J.C. (2001). Women middle manager's perception of the glass ceiling. Women in Management Review, 16(1), 30-41.

Knutson, B. J. ve Schmidgall, R. S. (1999). Dimensions of the glass ceiling in the hospitality industry. Cornell Hotel and Restaurant Administration Quarterly, 40(6), 64-75.

Kremer, H., Villamor, I. ve Ormiston, M. (2019). Princess bee effect: The reverse queen bee phenomenon. Academy of Management Proceedings, 1, 19515.

Lathabhavan, R. (2019). Glass ceiling beliefs, performance, and turnover intention through work engagement. International Journal Environment, Workplace and Employment, 5(4), 304-321.

Lookwood, N.R. (2004). The glass ceiling: domestic and international perspectives. Research Quarterly, Human Resource Magazine Research Quarterly, 1-49. 
Permatasari, D. ve Suharnomo, S. (2019). Investigating the "queen bee" phenomenon in Indonesia: A case study. Diponegoro International Journal of Business,2(1), 41-51.

Salles, A. ve Choo, E. (2020). Queen bee phenomenon: a consequence of the hive. The Lancet, 395(10228), 940.

Stroh, L.K., Brett, J.M. ve Reilly, A.H. (1996). Family structure, glass ceiling, and traditional explanations for the differential rate of turnover of female and male managers. Journal of Vocational Behavior, 49, 99-118.

Tekyazman, E.F. (2019). Spor eğitimi veren yükseköğretim kurumlarında kraliçe arı sendromu (Yüksek lisans tezi, Manisa Celal Bayar Üniversitesi Sosyal Bilimler Enstitüsü, Spor Yöneticiliği Ana Bilim Dalı, Manisa). https://tez.yok.gov.tr/UlusalTezMerkezi adresinden edinilmiştir.

Tolay, E. (2020). Kadın astların perspektifinden kadın yöneticiler: Hiyerarşik ilişkiler bağlamında nitel bir araştırma. İşletme Araştırmaları Dergisi, 12(3), 2276-2296. 